\title{
INFLUENCE OF CLIMATE REGIME ON CLOVER ROOT WEEVIL ADULT SURVIVAL AND PHYSIOLOGY
}

\author{
P.J. GERARD and E.D. ARNOLD \\ AgResearch, Ruakura Research Centre, Private Bag 3123, Hamilton, \\ New Zealand \\ Corresponding author: pip.gerard@agresearch.co.nz
}

\begin{abstract}
Clover root weevil adults collected from the field were held in four contrasting temperature, moisture and feeding regimes for a period of 10 weeks. Temperature was the main factor, inducing changes in adult wing muscle development and egg production. Egg production from females held in the 'moist winter' regime $\left(10^{\circ} \mathrm{C}, 8: 16 \mathrm{~h}\right.$ light:dark, moist conditions, ample food) increased linearly with time, with $90 \%$ of females fully reproductive at 10 weeks. In contrast, when held in the 'hot drought' regime $\left(20^{\circ} \mathrm{C} 16: 8 \mathrm{~h}\right.$ light:dark, dry conditions, intermittent food), the oviposition rate decreased logarithmically, with $32 \%$ of females fully reproductive at 10 weeks. Overall, adult mortality was lower in the 'moist' regimes (17\%) than the 'drought' regimes $(29 \%)$. Wing muscle development differed between regimes, ranging from $4 \%$ of adults with fully developed wing muscles in the 'moist winter' regime to $35 \%$ in the 'hot drought' regime. Clover root weevils are likely to oviposit throughout winter in most of New Zealand, but warm, dry summers will prevent a summer larval generation.
\end{abstract}

Keywords: Sitona lepidus, temperature, oviposition, wing muscle.

\section{INTRODUCTION}

Clover root weevil (CRW) (Sitona lepidus Gyllenhal (Coleoptera: Curculionidae)) was first identified in New Zealand in 1995 (Barratt et al. 1996) and is now found throughout farmland north of Taumarunui and east to Gisborne. Adults of the Sitona genus are long lived (Mowat \& Clawson 1996). Many Sitona species are univoltine, with adults passing through an aestivatory period before commencing oviposition; S. discoideus is one of these species (Sue et al. 1980; Goldson et al. 1984). However, CRW has at least two generations a year in Northern Ireland (Mowat \& Clawson 1996) and New Zealand (Gerard et al. 1999), with adults emerging in late spring/early summer and again in early autumn. The size of the summer larval generation varies from year to year, and is related to the proportion of reproductive females in the previous generation (Addison et al. 1998). Relatively low numbers of reproductively mature CRW females are present in hot, drought conditions. Conversely, numbers of reproductive females are high in years when conditions are favourable (Gerard et al. 1999) or when pastures are irrigated (Willoughby \& Hardwick 1999).

Although the proportion of reproductive females in field populations of CRW are related to climatic conditions, little is known about how and when the changes in physiology are initiated, and how rapidly they occur. This paper reports on a laboratory experiment that examines whether changes in adult reproductive physiology can be induced in post-teneral CRW adults by simulating different climate regimes.

\section{METHODS}

CRW adults were collected from a Waikato pasture in April 2001 using a suction apparatus (modified Homelite HB180V blower/vac.) and sorted into batches of 50. Each 
batch was placed in the mesh-based top of a two-tier cage (Goldson et al. 1992). Four replicate cages of adults were held at each of the following treatments:

- Moist winter: $10^{\circ} \mathrm{C}, 8: 16 \mathrm{~h}$ light:dark, moist atmosphere, surplus food

- Cool moist summer: $15^{\circ} \mathrm{C}, 16: 8 \mathrm{~h}$ light:dark, moist atmosphere, surplus food

- Cool drought: $15^{\circ} \mathrm{C}, 16: 8 \mathrm{~h}$ light:dark, limited food supply

- Hot drought: $20^{\circ} \mathrm{C}, 16: 8 \mathrm{~h}$ light:dark, limited food supply

Adults were provided with a supply of white clover (Trifolium repens) leaves, the stems of which were inserted into a vial of water to prevent wilting. Those receiving limited food consumed all clover foliage and had 1-2 days starvation before fresh clover was provided. The 'moist' atmosphere was provided by a damp paper towel laid over the gauze cage lid. Feed supply and dampness of the paper towel were monitored daily. Eggs that had accumulated in the lower tier of the cages were removed and weighed at weekly intervals. Dead adults were removed and frozen at $-20^{\circ} \mathrm{C}$. At 10 weeks, the experiment was terminated and all live and dead weevils dissected to determine sex. All live weevils were scored on a scale of 1-3 for development of wing muscles (from $0=$ no muscles to $3=$ muscles occupying the entire thoracic cavity), and the females scored $0-5$ for sexual development (from $0=$ undeveloped oviducts to $5=$ fully developed reproductive system containing mature eggs) (Barker et al. 1988). Weekly live male and female numbers, and egg production (mg eggs/female) were estimated retrospectively for each replicate using the dissection data and total counts.

Statistical analysis

Regression analysis was used to explore the changes in egg production with time. Treatment effects were compared by analysis of variance, using LSD for separation between treatment means $( \pm$ SEM).

\section{RESULTS}

Mortality and reproductive physiology results are summarised in Table 1 . Mortality was high across all treatments in the first week (overall mean \% dead 19.0 \pm 1.8 ), but levelled off for the remainder of the experiment (final overall mean 22.9 \pm 2.3 ). Mortality was lower in the 'moist' treatments than the 'drought' treatments $(17$ versus $29 \% ; \mathrm{P}<0.01)$. Significant differences were found in flight muscle development at 10 weeks $(\mathrm{P}<0.05)$, with fewer adults with fully developed flight muscles in the moist winter regime than in the cool moist summer and hot drought regimes. A higher percentage of females held in the moist winter regime had fully mature reproductive systems than did females held in hot drought conditions $(\mathrm{P}<0.05)$.

TABLE 1: Clover root weevil mortality, adult wing muscle development and female reproductive maturation after exposure to four climate regimes for 10 weeks.

\begin{tabular}{lccc}
\hline Regime & $\begin{array}{c}\text { \% mortality } \\
\text { \%uscles }\end{array}$ & $\begin{array}{c}\% \text { fully reproductive } \\
\text { females }\end{array}$ \\
\hline $\begin{array}{l}\text { Moist winter } \\
10^{\circ} \mathrm{C}, 8: 16 \mathrm{~L}: \mathrm{D}^{1} \text {, moist, surplus food }\end{array}$ & 18 & 4 & 90 \\
$\begin{array}{l}\text { Cool moist summer } \\
15^{\circ} \mathrm{C}, 16: 8 \mathrm{~L}: \mathrm{D} \text {, moist, surplus food }\end{array}$ & 15 & 24 & 69 \\
Cool drought & 31 & 18 & 71 \\
$15^{\circ} \mathrm{C}, 16: 8 \mathrm{~L}: \mathrm{D}$, limited food & 37 & 35 & 32 \\
Hot drought & 27 & 16 & 39 \\
$20^{\circ} \mathrm{C}, 16: 8 \mathrm{~L}: \mathrm{D}$, limited food & 13 & 16 &
\end{tabular}

${ }^{1} \mathrm{~h}$ light:dark. 
Egg production by females held in the moist winter regime increased in a linear manner with time (Fig. 1, $\mathrm{P}<0.01$ ). Total egg production from adults held in the moist and drought cool regimes did not significantly from each other, and tended to show an early peak at week 2 or 3 , a general decline till week 8, then an increase at week 10 (Fig. 2). Egg production at the hot drought regime decreased logarithmically with time (Fig. 3, $\mathrm{P}<0.001$ ). Total egg production was significantly higher in the two 'cool' regimes than the other two treatments $(\mathrm{P}<0.01)$. Overall, egg production from the two 'moist' regimes did not significantly differ from the 'drought' regimes.

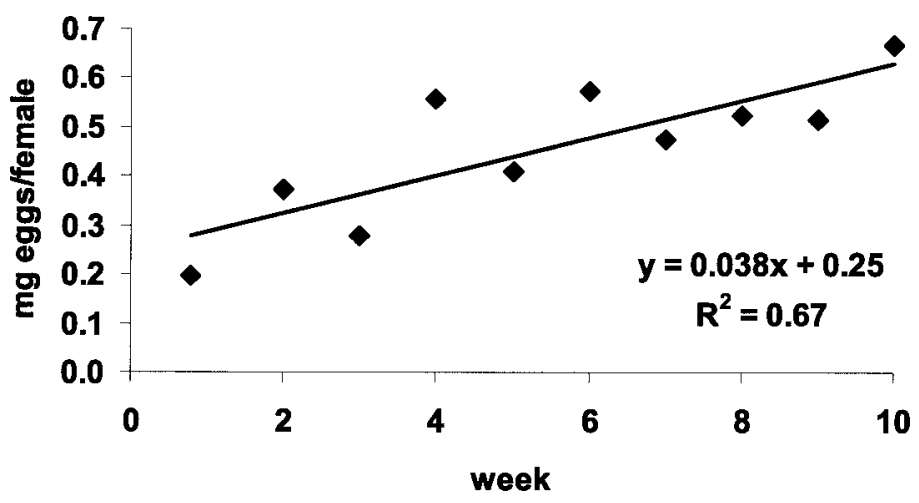

FIGURE 1: Change in egg production of clover root weevil adults held in a 'moist winter' regime $\left(10^{\circ} \mathrm{C}, 8: 16 \mathrm{~h}\right.$ light:dark, moist conditions and with surplus food).

\section{DISCUSSION}

The above results demonstrate that changes in CRW adult wing muscle and reproductive physiology can be induced by exposure to contrasting environmental regimes. This supports the conclusions of Addison et al. (1998) and Willoughby \& Hardwick (1999) that the low levels of fully reproductive females observed in field populations in hot dry summers were a physiological response to adverse conditions

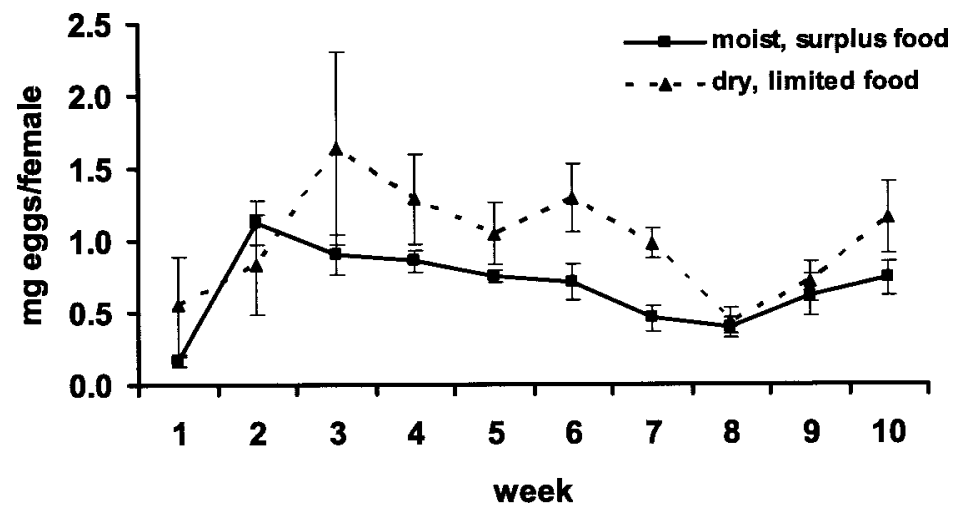

FIGURE 2: Effects of 'cool moist summer' and 'cool drought' regimes on egg production when clover root weevil adults were held at $15^{\circ} \mathrm{C}$ in $16: 8 \mathrm{~h}$ light:dark. Values are the mean \pm SEM. 


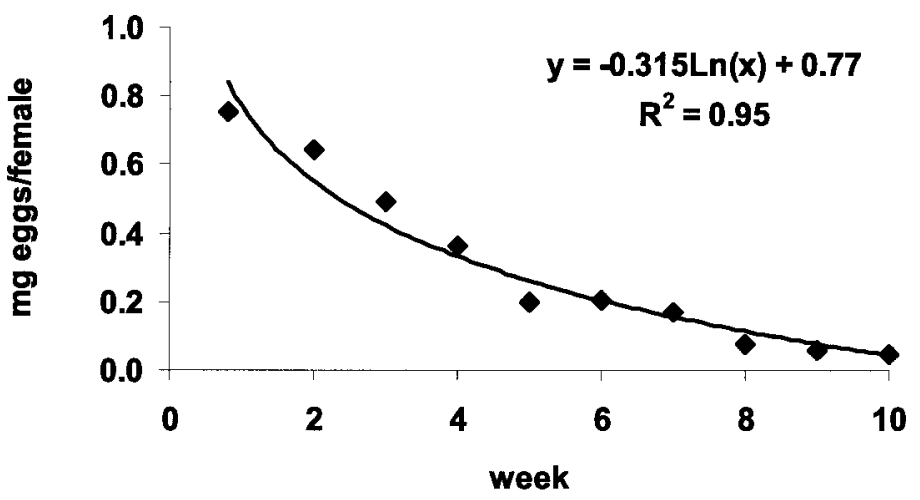

FIGURE 3: Change in egg production of clover root weevil adults held in a 'hot, drought' regime $\left(20^{\circ} \mathrm{C}, 16: 8 \mathrm{~h}\right.$ light:dark, dry conditions and with limited food).

rather than differential adult migration. The two-fold differences between the hot drought and cool drought regimes in both wing development and female reproductive maturation suggest temperature is a key factor. This ability to switch between flying and reproductive phases in CRW differs from the apparently obligatory change in reproductive physiology observed in aestivatory Sitona species. For example S. discoideus, the only other Sitona species currently recorded in New Zealand, develops flight muscles during the feeding stage after eclosion and flies to aestivation sites in summer. At these sites the weevils autolyse their flight muscles, then after aestivation, reconstruct them for a return flight in autumn. The females become reproductive only when they are re-established in the crop (Goldson et al. 1984). Other Sitona spp. may also have facultative adult physiology similar to CRW. Jackson (1933) observed flightless $S$. hispidulus individuals within populations and obtained evidence that environmental conditions during development were responsible.

Many Sitona spp. feed on annual legumes, whereas the preferred host plant for CRW is white clover, a perennial. Therefore, instead of evolving aestivatory behaviour, CRW has evolved the ability to fully exploit good oviposition and feeding opportunities, or to disperse from inhospitable sites in search of new sites by flight. In addition, the results presented in this paper show there is considerable variation between individuals within the population. For example in the cool moist summer regime $24 \%$ of adults had fully developed wing muscles and $69 \%$ of females were fully reproductive. Therefore, even when there is a surplus food supply, a proportion of the CRW adult population has dispersal capability, should temperatures be conducive for flight or the food become limiting.

Figure 2 shows that more eggs tended to be laid in the cool drought regime than in the cool moist summer regime after week 2, and the difference in oviposition rates was relatively constant, except weeks 8 and 9 . As there was no significant difference between regimes in percentage reproductive females at 10 weeks (Table 1), it appears that fully reproductive females in the drought regime were more fecund than those in the moist regime. This could be an artefact of the $31 \%$ mortality in the drought regime (the less fit females had died during the initial weeks of the experiment), compared with the $15 \%$ mortality in the moist regime.

The steady increase in oviposition rate in the population held in the $10^{\circ} \mathrm{C}$ moist winter regime indicates that CRW are likely to oviposit throughout the winter in many New Zealand regions. The results also support the Mowat \& Clawson (1996) conclusion that a short photoperiod does not inhibit CRW oviposition. Finnish data has shown that the 
lower threshold for CRW oviposition is about $7^{\circ} \mathrm{C}$ (Markkula 1959). Mean daily minimum air temperatures exceed $7^{\circ} \mathrm{C}$ in winter from Auckland northwards and mean winter air temperatures are around $10^{\circ} \mathrm{C}$ or above in more southern North Island intensive pastoral regions, e.g. Bay of Plenty and Taranaki (NIWA 2002).

Conversely, the combination of increased adult mortality and the logarithmic decline in oviposition rate in the hot drought regime indicates that warm and dry summers will hinder the establishment of a summer larval generation. In regions where this type of summer is common, such as the East Coast of the North Island, Canterbury and inland Otago, CRW may predominantly exhibit a univoltine life cycle. However, as many adults in the population will have flight capability, irrigated pastures in these regions may be vulnerable to rapid colonisation.

\section{ACKNOWLEDGEMENTS}

This work was funded by the Foundation for Research, Science and Technology.

\section{REFERENCES}

Addison, P.J.; Willoughby, B.E.; Hardwick, S.; Gerard, P.J. 1998: Clover root weevil: Observations on differences between 1997 and 1998 summer populations in the Waikato. Proc. 51st N.Z. Plant Prot. Conf: 1-4.

Barker, G.M.; Prestige, R.A.; Pottinger, R.P. 1988: Reproductive phenology of Listronotus bonoriensis (Kuschel) in northern New Zealand pastures. Bull. Entomol. Res. 78: 659-668.

Barratt, B.I.P.; Barker, G.M.; Addison, P.J. 1996: Sitona lepidus Gyllenhal (Coleoptera: Curculionidae), a potential clover pest new to New Zealand. N.Z. Entomol. 19: 23-30.

Gerard, P.J.; Addison, P.J.; Hardwick, S.; Willoughby, B.E .1999: Establishment of the invader: Insights into life history and biology of Sitona lepidus in the Waikato region of New Zealand. Proc. 7th Australasian Conf. Grassland Invert. Ecol.: 43-51.

Goldson, S.L.; Frampton, E.R.; Barratt, B.I.P.; Ferguson, C.M. 1984: The seasonal biology of Sitona discoideus Gyllenhal (Coleoptera: Curculionidae), an introduced pest of New Zealand lucerne. Bull. Entomol. Res. 74: 249-259

Goldson, S. L.; McNeill, M.R.; Phillips, C.B.; Proffitt, J.R. 1992: Host specificity testing and suitability of the parasitoid Microctonus hyperodae (Hym.: Braconidae, Euphorinae) as a biological control agent of Listronotus bonariensis (Col.: Curculionidae) in New Zealand. Entomophaga 37: 483-498.

Jackson, D.J. 1933: Observations on the flight muscles of Sitona weevils. Ann. Appl. Biol. 20: 731-770.

Markkula, M. 1959: The biology and especially the oviposition of the Sitona Germ. species occurring as pests of leguminous plants in Finland. Publ. Finn. State Agric. Res. Board. 178: 41-74.

Mowat, D.J.; Clawson, S. 1996: Oviposition and hatching of the clover weevil Sitona lepidus Gyll. (Coleoptera: Curculionidae). Grass Forage Sci. 51: 418-423.

NIWA 2002: NIWA Educational Resources web page. http://www.niwa.co.nz/edu/ resources/climate $(5 / 4 / 02)$.

Sue, K.; Ferro, D.N.; Emberson, R.M. 1980: Life history and seasonal ovarian development of Sitona humeralis (Coleoptera: Curculionidae) in New Zealand. N.Z. Entomol. 7: 165-169.

Willoughby, B.; Hardwick, S. 1999: Effects of summer irrigation on population dynamics and reproductive status of adult Sitona lepidus in the Waikato. Proc. 52nd N.Z. Plant Prot. Conf:: 245-249. 